\title{
Verification of the water supply rules in an arid area: a case study of the Xayar irrigation district in the northern part of the Taklamakan Desert
}

\author{
T. Yamamoto ${ }^{1}$, A. Jalaldin ${ }^{2} \&$ T. Nagasawa ${ }^{3}$ \\ ${ }^{1}$ Research Faculty of Agriculture, Hokkaido University, Japan \\ ${ }^{2}$ College of Resources and Environmental Sciences, \\ Xinjiang University, China \\ ${ }^{3}$ Hokkaido University, Japan
}

\begin{abstract}
Chronic water shortage is a major problem in the Tarim River Basin. Countermeasures to overcome this shortage include water supply management and water-saving irrigation, unless a new water resource can be developed. Here we examined the status and adequacy of water supply management and the problems with agricultural water use in this area. The research field was the Xayar district located in the northern part of the Taklamakan Desert, Xinjiang, China. The water management office provided data for the monthly irrigated water volume that was supplied to the districts, and the township water management office provided data for the daily water supply. In addition, we interviewed the water management staff and farmers. The results indicated that the water supply rules were considered rational in this area. However, the enforcement of these rules was not strict, particularly on the borders of the irrigation channel compared with the upper irrigation district. This study demonstrated that the basic rules were strictly observed under the direct control of the water management office, and the rules were flexible, depending on each condition, through direct correspondence with farmers.
\end{abstract}

Keywords: irrigation, water distribution rule, arid region. 


\section{Introduction}

Recently, agricultural production has increased in the Tarim River Basin, Taklamakan Desert, Xinjiang, China. This has been brought about through breeding improvements, advancement in fertilization management, and introduction of new and larger agricultural machinery, etc. However, the extent of production development will ultimately depend on the cultivable area and the water resources available. Chronic water shortage is a major problem in this area, and the overstrained demand caused by the development of the cultivated area as it stands has created significant problems. During the past 50 years, the irrigated area has increased 3.6-fold and irrigation water volumes have also increased 3.1-fold. Reflecting this, the annual average discharge of the Tarim River has dropped from $51.8 \times 10^{8} \mathrm{~m}^{3}$ in the $1960 \mathrm{~s}$ to $42.0 \times 10^{8} \mathrm{~m}^{3}$ in the $1990 \mathrm{~s}$ [1]. Moreover, the annual average salt content of the river has increased from $0.75 \mathrm{~g} / \mathrm{L}$ in the $1960 \mathrm{~s}$ to $2.6 \mathrm{~g} / \mathrm{L}$ in the $1990 \mathrm{~s}$ [2].

The problems of water shortage and salinization of river irrigation water have led to the use of groundwater for irrigation [3]. However, groundwater resources are limited, and its use will affect the environment. Therefore, it is necessary to enhance the utilization of surface (river) water as a realistic countermeasure.

In this study, we considered the adequacy of the water supply and identified problems associated with the distribution rules on agricultural water use in Xayar County, Tarim River basin, China.

\section{Methods and outline of study area}

The study area was Xayar prefecture in Xinjiang Uygur Autonomous, China. Xayar County is located in the Ugen River Basin which is one of the branches of the Tarim River. The lower administrative level in the county are the "townships and towns," and there are eight of these in Xayar County (from upstream: Honqi, Yingmaili, Nuerbake, Hailou, Xayar town, Xinkennongjiao, Gulibake, and Tuoybao). Agricultural water supply in this prefecture depends mainly on the Ugen River. In this specific study area, irrigation water is supplied from both the Ugen River and groundwater, and border irrigation is widely used on the farmland. The introduction of water-saving irrigation has taken place in this county, and the adoption rate is around $20-30 \%$ at present [3]. There are many family farmers in this irrigation district. However, some farmland has also been developed by national enterprises in Xinkennongjiao, and there are many capitalist farmer landowners [4].

To understand the state of agricultural water use, management of water-saving irrigation and agricultural production interviews were conducted with representatives of agency branch offices and farmers from 2003 to 2011. Discharge data were supported by Xinjiang University researchers' group analysis. The data used were the water supplied to each town or township during 1998-2008 and daily water distribution data to each farmer in Nuerbake in 2008-2011. 


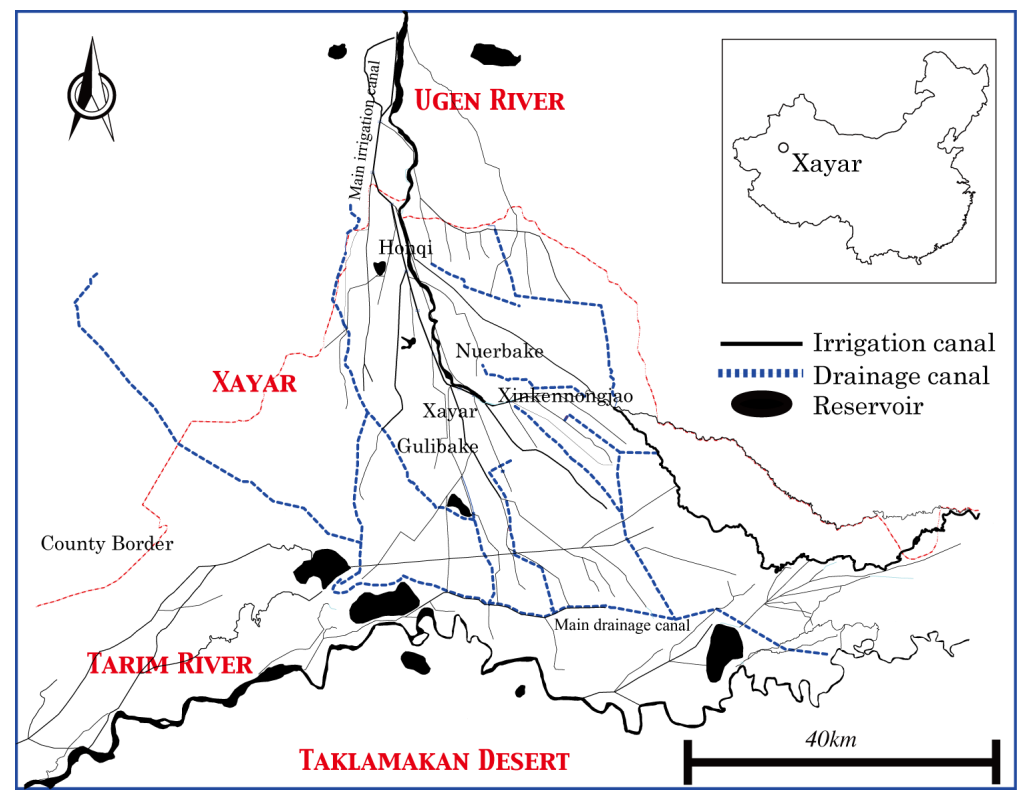

Figure 1: Overview of the study site.

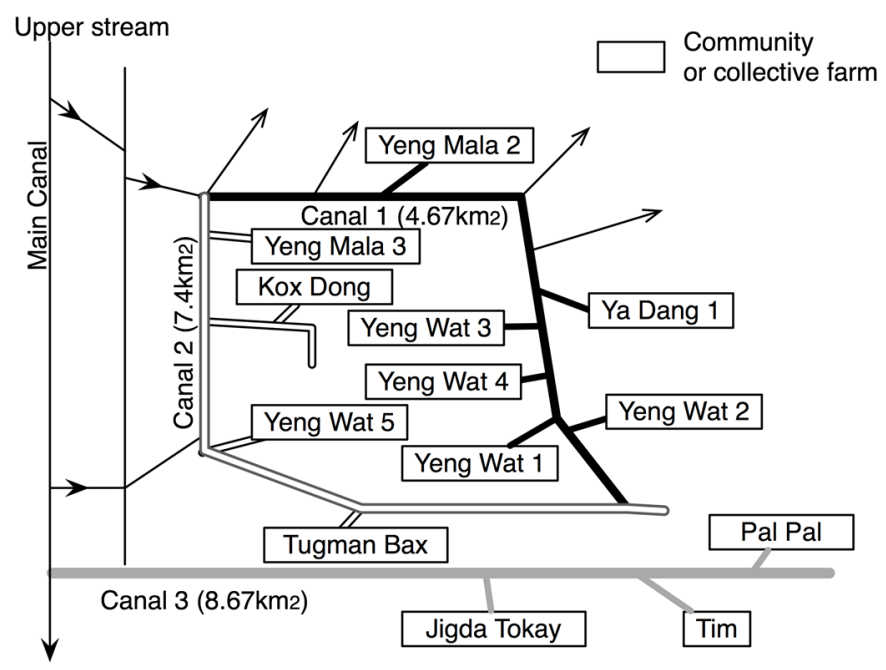

Figure 2: Outline of irrigation canals in the Nurback Township.

According to the annual account of the water management agency, daily water distribution data were recorded from the previous October to the September of the reference year. 


\section{Results}

\subsection{The rules of water supply in Xayar district}

Xayar water management agency has charge of the water supply from the main canal to the town or townships; it is virtually supply-driven. Basically, the water management agency shares the water according to the crop acreage and the requirement of each crop. However, they cannot satisfy the demand for water in the case of severe water shortage. Thus, they have established some priority rules [4]. Although these rules are common around this district, there are also some districts that have not only these rules but also are considered for more wells.

During spring to summer (seeding-growing):

1) Upstream takes priority over downstream.

2) Large canals (or irrigation blocks) take priority over smaller canals.

Methods to implement minimum seepage of water are taken during the dry season because many irrigation ditches are not lined; therefore, this is regarded as reasonable water distribution during this time.

In winter:

1) Downstream takes priority over upstream because water shortages are more likely to be downstream at sowing time.

2) Wheat fields for subsistence cropping and small scale farmers with land under 30 year contracts take priority.

These rules aim to preserve water at the beginning of spring due to water being stored in the fields in the frozen soil in winter.

\subsection{Actual condition of water supply in Xayar County}

If the water distribution rules are strictly managed, results should be seen in the water supply volume in this prefecture. We obtained the minimum supplied water volume from the monthly water supply of the main canal (1998-2008) and confirmed the volume of water supplied to each town or township at that time (Table 1). In general, the supplied water volume was higher in Xinken-nongchang, where there is a national project, than in other townships. In other townships, there was a tendency for more water to be supplied to the townships more upstream rather than downstream. In addition, there was a tendency for the supplied water to increase in the downstream townships compared with the upstream townships during winter irrigation. Furthermore, the clear tendency of upstream priority was not shown in the seeding period (March and April) and autumn (October and November). In winter, there was a trend for the supplied water to be higher for downstream townships compared with upstream townships. However, this could not be confirmed in the lowest township. 
Table 1: $\quad$ Monthly supplied water volume to each township in the dry months during 1998-2008.

\begin{tabular}{|c|c|c|c|c|c|c|c|c|c|c|}
\hline & & \multicolumn{3}{|c|}{ Upper $\leftarrow$} & \multicolumn{2}{|c|}{ Location } & \multicolumn{2}{|c|}{$\rightarrow$ Lower } & \multirow[b]{2}{*}{ 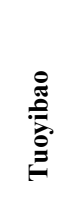 } & \multirow[b]{2}{*}{ 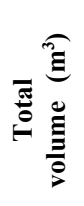 } \\
\hline & & تَّ & 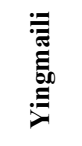 & 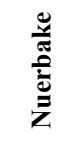 & 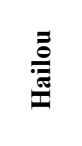 & $\underset{\bar{x}}{\bar{\pi}}$ & 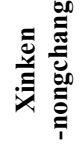 & 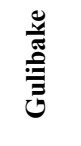 & & \\
\hline Feb. & 2008 & 11.0 & 8.3 & 14.8 & 9.0 & 0.0 & 9.1 & 25.4 & 13.2 & 84 \\
\hline Mar. & 2003 & 183.8 & 191.7 & 146.2 & 166.7 & 207.4 & 219.8 & 164.4 & 125 & 1060 \\
\hline Apr. & 2008 & 43.6 & 30.3 & 42.6 & 29.7 & 85.0 & 36.3 & 67.7 & 58.3 & 301 \\
\hline May & 199 & 24.2 & 42.0 & 29.3 & $\overline{30.6}$ & 24.8 & & 32.9 & 28.7 & 172 \\
\hline June & 1999 & 122.8 & 122.0 & $\underline{88.8}$ & 113.5 & 116.3 & 109.8 & 93.6 & 107.1 & 622 \\
\hline July & 2001 & 240.9 & 249.1 & $2 \overline{07.3}$ & 240.6 & 205.1 & 395.7 & 237.7 & 215.4 & 1454 \\
\hline Aug. & 2000 & 177.4 & 168.4 & $\overline{123.3}$ & 102.9 & 174.4 & 199.2 & 161.3 & 125.6 & 858 \\
\hline Sept. & 2006 & 158.9 & 136.8 & 112.7 & 102.8 & $\underline{70.1}$ & 39.1 & 84.0 & 87.9 & 678 \\
\hline Oct. & 2003 & 15.0 & 26.8 & 2.4 & 52.0 & 6.1 & 0.0 & 29.1 & 7.5 & 138 \\
\hline Nov. & 2000 & 202.0 & 125.3 & $10 \overline{8.4}$ & 173.0 & 185.7 & 72.3 & 146.9 & 143.3 & 855 \\
\hline Dec. & 2003 & 101.5 & 84.6 & 102.8 & 139.4 & 93.0 & 391.9 & 172.0 & 131.4 & 89 \\
\hline
\end{tabular}

This table shows the monthly supplied water volume of each town or townships when the monthly supplied water volume to the district was smallest in same month during the survey period.

The values of Xinkennongchang have been excluded from examination.

Shaded cells: Maximum value in each month.

Bold and underlined characters: Minimum value in each month, ( $\mathrm{mm} / \mathrm{month})$.

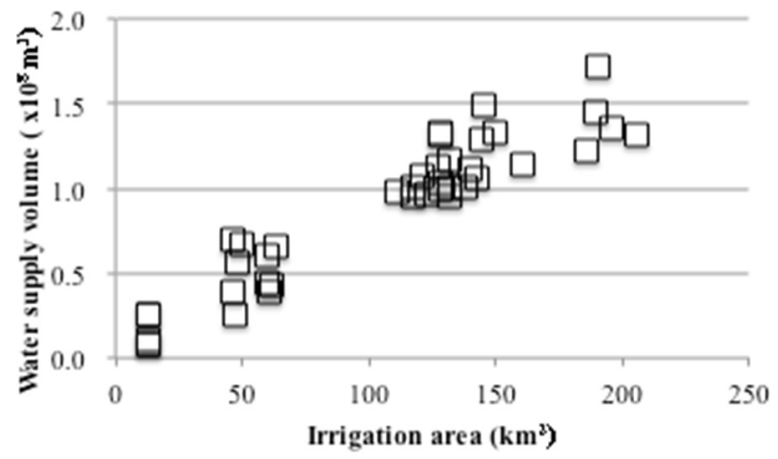

Figure 3: Relationship between the water supply volume and irrigation area in each township.

The volume of the supplied water increased with expanding irrigation area (Figure 3). Therefore, it is clear that the water distribution rule indicating upstream priority in severe water shortage periods is limited during the growing period (May to September), and the most upstream townships take priority. It is also clear that the water supply for a district is influenced by the irrigation area. 


\subsection{Case study of water management in the Nuerbake Township}

We verified the water distribution rules in the Nuerbake Township, Xayar County. The township holds 11 large villages and 7 collective farms. Basically, the villages have 3-5 communities (little villages) that are of minimum unit size for water management. Three main canals flow through this township. Table 2 shows the water supplied to each canal in Nuerbake in 2008-2011. Here it appears that the supplied water volume is sufficient, but around $40 \%$ of this volume can be considered as supplemental water requirement when considering irrigation efficiency because these values indicate water intake at the division gate [5]. Each canal carries irrigation water to some communities, (Figure 2) and we can confirm the priority of upstream canals in many cases. Canals 1 and 2 are located in the upper part of this township and the water volume is larger in Canal 1 compared with the others. This indicates upstream priority. Comparing the irrigation area and the supplied water volume, the supplied water volume increases with the irrigation area in Canal 2 (Figure 4). Overall, a low relationship is observed between the irrigation area and the supplied water volume.

Table 2: $\quad$ Supplied water volume (mm/year) of each canal in the Nuerbake Township.

\begin{tabular}{l|rrrr}
\hline & 2008 & 2009 & 2010 & \multicolumn{1}{c}{2011} \\
\hline \hline Canal 1 & 1253.3 & 1004.6 & 1177.2 & 1499.6 \\
Canal 2 & 1193.5 & 965.2 & 1136.4 & 1503.8 \\
Canal 3 & 983.0 & 712.3 & 663.1 & 697.7 \\
\hline
\end{tabular}

According to the annual account of the water management agency, daily supplies water data was recorded from the previous October to the September of the reference year.

With regard to the water supplied to upstream and downstream communities, priority was intended to be given to upper villages (Table 3 ). This was particularly noteworthy in the dry year of 2009. However, the fact that the water supplied to an area depended on the irrigation area was not accepted in communities of Canals 1 and 3 (Figure 4). Winter priority of downstream irrigation was not observed because water supply in winter (November, December, and January) was greater in Canals 1 and 2 than in Canal 3 (Figures 5-7). The irrigation for wheat showed less difference than other crops (Figures 5-7). Thus, the priority of irrigation for wheat is accepted. Moreover, the irrigation district in Canal 3 was developed as collective farms and there are few subsistence farmers. Many collective farms growing cash crops have their wells available for irrigation; therefore, the shortage of irrigation water does not affect them as much as the small farmers, where it may be a case of survival.

We suggest that the reason that the basic water distribution rules at a village level are not strictly preserved is due to irrigation history, the growth condition of each crop, or the community (the particular relationships between the water management staff and some farmers or others in the village). 
Table 3: Comparison of the difference in location and the supplied water volume.

\begin{tabular}{|c|c|c|c|c|c|}
\hline & location & 2008 & 2009 & 2010 & 2011 \\
\hline \multirow[t]{2}{*}{ Canal 1} & upper & 1241.3 & 1023.5 & 1412.5 & 1580.4 \\
\hline & down & 1294.3 & 932.4 & 1277.3 & 1554.3 \\
\hline \multirow[t]{2}{*}{ Canal 2} & upper & 1332.4 & 1170.5 & 1431.9 & 1522.9 \\
\hline & down & 1033.7 & 737.0 & 1044.4 & 1214.8 \\
\hline \multirow[t]{2}{*}{ Canal 3} & upper & 779.7 & 828.2 & 737.1 & 1018.4 \\
\hline & down & 471.5 & 245.2 & 0.0 & 298.8 \\
\hline
\end{tabular}

The classification of upper and down location in each canal depends on the village location indicated in Figure 2.

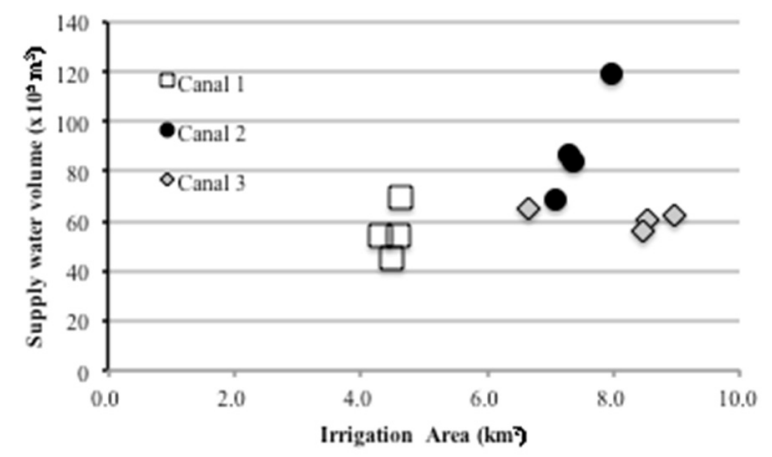

Figure 4: Relationship between the irrigated area and the supplied water volume.

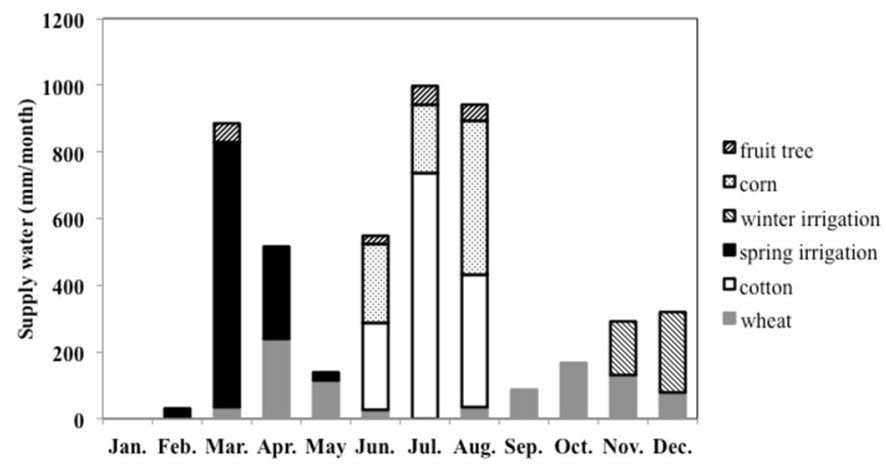

Figure 5: $\quad$ Supplied water volume in Canal 1 (average of 2008-2011). 


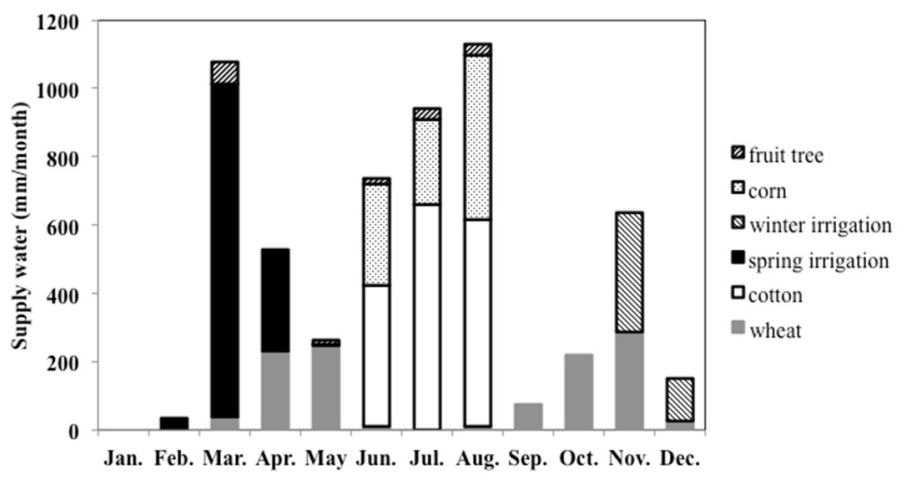

Figure 6: Supplied water volume in Canal 2 (average of 2008-2011).

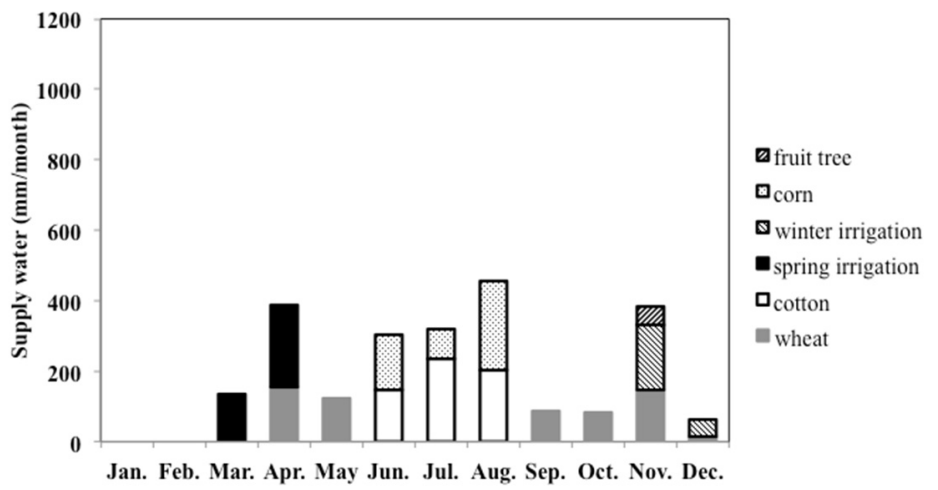

Figure 7: Supplied water volume in Canal 3 (average of 2008-2011).

\section{Conclusion}

The basic rules of the amount of water supplied to various fields during water shortages were verified through water management records from each level of the government, namely, prefecture, township, and village. Although all the rules are reasonable, the enforcement of the rules is somewhat weak. In particular, we noticed a trend that the strict enforcement of these rules failed toward the periphery of the irrigation districts. The enforcement of basic rules is observed in the district that is directly under the control of the water management agency. Water management rules are modified to reflect the conditions of the township water management offices or water management staff who are associated with the farmers. However, the order of priority in the distribution rules must be considered to improve water management. For example, the irrigation for subsistence crops should take priority over others. Although the current priority of the downstream 
fields is low, which ignores the water requirement of crops, due to the water seepage occurring in the canals, equality could be improved thorough the collectivization of crops or the exchange and consolidation of fields and adequate water management.

\section{Acknowledgements}

This research was supported by Xayar County Government, Xayar Water Resource Agency, Xinjiang University, and Xinjiang Uyghur Autonomous Region Water Resource Agency. Analyses were supported by Daisuke Nakagawa (Japan Overseas Cooperation Volunteers). This work was supported by JSPS KAKENHI Grant Number 21405031.

\section{References}

[1] Abudoureyimu, B., Kido, Y., Tanaka, Y. \& Nakakita, E., Groundwater analysis of Tarim River Basin in Xinjiang-2-dimensional Saturate Ground water Flow Model Analysis -, Annuals of Disas. Prev. Res. Inst, Kyoto Univ., 51B, pp. 581-590, 2008.

[2] Hongwei, Z., Yudong, S. \& Shunjun, H., Irrigated agriculture and sustainable water management strategies in the Tarim Basin, Proc. of the workshop New Approaches to water management in Central Asia, Aleppo, Syria, pp. 6-11, 2000.

[3] Jalaldin, A., Tadao, Y., Oikawa, T. \& Tetuaki, N., Influences of agricultural irrigation on regional salinity balance in arid areas of northwestern China, International Journal of Environment and Rural Development, 3(1), pp. 108-113, 2012.

[4] Yamamoto, T., Jalaldin, A., Maimaidi, A. \& Nagasawa, T., Land reclamation and water management in an arid region: a case study of Xayar County in Xinjiang Uyghur autonomous region, China, Sustainable Irrigation Management, Technologies and Policies III, WIT Press, pp. 3-14, 2010.

[5] Tadao, Y., Jalaldin, A., Maimaidi, A. \& Tetuaki, N., The Present Condition and Problem of Agricultural Water Management in Northern Part of Taklamakan Desert. International Journal of Environment and Rural Development, 1(1) pp. 50-55, 2010. 